\title{
Urgences
}

\section{Je longe des murs...}

\section{Robert Laniel}

Numéro 20, mai 1988

Appellation contrôlée

URI : https://id.erudit.org/iderudit/025471ar

DOI : https://doi.org/10.7202/025471ar

Aller au sommaire du numéro

Éditeur(s)

Urgences

ISSN

0226-9554 (imprimé)

1927-3924 (numérique)

Découvrir la revue

Citer ce document

Laniel, R. (1988). Je longe des murs... Urgences, (20), 26-26.

https://doi.org/10.7202/025471ar

Ce document est protégé par la loi sur le droit d'auteur. L'utilisation des services d'Érudit (y compris la reproduction) est assujettie à sa politique d'utilisation que vous pouvez consulter en ligne.

https://apropos.erudit.org/fr/usagers/politique-dutilisation/
Cet article est diffusé et préservé par Érudit.

Érudit est un consortium interuniversitaire sans but lucratif composé de l'Université de Montréal, l'Université Laval et l'Université du Québec à Montréal. Il a pour mission la promotion et la valorisation de la recherche. https://www.erudit.org/fr/ 


\section{ROBERT LANIEL}

Je longe des murs de verre

un château

feuillage épars

aucune grille

géométries planes que ces sphères

tessons de lumière ou étoiles ou

plus de gauche ni de droite

et le nord et l'ouest

le silence ronge ces nébuleuses

miroirs infernaux comme un deuil

plus de secret

c'est l'absence

j'habite sous cette avalanche de ténèbre

se mêlant à mon sang 